\section{Histologic and Tomographic Findings of Bone Block Allografts in a 4 Years Follow-up: A Case Series}

Daniel Deluiz ${ }^{1,2}$, Luciano Santos Oliveira ${ }^{2}$, Paul Fletcher ${ }^{3}$, Fábio Ramôa Pires ${ }^{4}$, Justine Monnerat Tinoco ${ }^{5}$, Eduardo Muniz Barretto Tinoco ${ }^{1}$

\author{
'Department of Periodontology, UERJ \\ - Universidade do Estado do Rio de \\ Janeiro, Rio de Janeiro, RJ, Brazil \\ ${ }^{2}$ Department of Implantology, \\ PUC-Rio - Pontifícia Universidade \\ Católica, Rio de Janeiro, RJ, Brazil \\ ${ }^{3}$ Department of Periodontology, \\ Columbia University College of Dental \\ Medicine, New York, NY, USA \\ ${ }^{4}$ Department of Oral Pathology, UERJ \\ - Universidade do Estado do Rio de \\ Janeiro, Rio de Janeiro, RJ, Brazil \\ ${ }^{5}$ Department of Endodontics, UERJ \\ - Universidade do Estado do Rio de \\ Janeiro, Rio de Janeiro, RJ, Brazil
}

Correspondence: Daniel Deluiz, Boulevard 28 de Setembro, 157 - $2^{\circ}$ andar - sala 10, 20551-030 Rio de Janeiro, RJ, Brasil. Tel.: +55-21-99647-2777. e-mail: d.deluiz@implanto-puc.org

Key Words: bone allografts; alveolar ridge augmentation; bone graft

\section{Introduction}

Bone substitutes have been widely used in dentistry to regenerate alveolar ridge defects and to allow the placement of dental implants. Although several bone augmentation techniques and various biomaterials are available to the clinician, the reconstruction of severe alveolar bone deficiencies still present a challenge in oral implantology (1).

Autologous bone is considered the gold standard grafting material due to its osteogenic, osteoinductive and osteoconductive properties, which are thought to emanate from the viable cells as well as bone morphogenetic proteins, osseous scaffold and extracellular matrix (2). Despite its positive qualities, alternatives to autologous bone are often needed due to their limited availability, harvest site morbidity and complications associated with proximity to nerve and arteries (3).

Fresh-frozen bone allografts (FFBA), available from musculoskeletal tissue banks, have been well documented clinically and demonstrated positive results as an alternative to autografts during alveolar reconstruction (4). Published case series demonstrating implant survival and early histologic outcomes in regenerated sites are widely available, but long term data on graft incorporation and its functionality are still scarce $(5,6)$.

The long-term evaluation of bone grafts in dentistry is limited and most often made by assessment of implant survival or by imaging techniques (CT and/orX-Ray imaging techniques) $(7,8)$. In dentistry, long-term bone graft biopsies after implant loading are usually not performed in humans for obvious ethical reasons. This however is a more common practice in orthopaedics where revision surgery is frequently performed, thus providing the surgeon with an opportunity to harvest samples for histological analysis $(9,10)$.

The aim of this study is to report the histologic and tomographic findings in 4 patients of FFBA bearing dental implants in functional occlusion 4 years after the insertion of the definitive prosthetic restoration. This is, to the best of the authors' knowledge, the first time such long term data have been made available in dentistry.

\section{Case Report}

Four patients ( 1 male and 3 female), aged 44 to 52 years (mean: $47.5 \pm 9.98)$, enrolled in a clinical trial evaluating the short-(11) and long-term outcomes of FFBA at the Department of Implantology of the Pontifical Catholic University (Rio de Janeiro, Brazil) were included in this report. The original study protocol was approved by the Ethics Committee of University Hospital Pedro Ernesto (CEP- HUPE, 2762/2010) and it is in accordance with the Helsinki Declaration. All of the eligible patients signed informed consent forms. 
At the time of the present evaluation, the individuals were currently rehabilitated with implant-supported fixed ceramic restorations that had been in occlusion for approximately 4 years (mean: $48.25 \pm 3.5$ months). The patients underwent maxillary horizontal alveolar ridge augmentation with onlay block FFBA before implant placement. All the augmentations used FFBA alone, with no other bone substitutes or barriers. The implants were placed after a 4-month graft healing period and were submerged for 12 weeks prior to their loading. Subsequently, all the patients received the final prosthesis on the implants placed in the grafted sites. This time point was considered the baseline.

The eligible individuals required either mucogingival surgery or the placement of additional implants at sites near previously grafted ridges. The additional surgical procedure was undertaken to improve esthetics or to complement the first treatment plan. The patients were already being followed-up clinically and by cone-beam computed tomography (CBCT) for the original research and none of the grafted areas or the dental implants presented problems or infection.

Bone block allografts utilized in the initial reconstructive surgery were fragments of cortico-cancellous proximal tibia, cancellous tibia and iliac crest and were provided by the Musculoskeletal Tissue Bank of the National Institute of Traumatology and Orthopedics (INTO) according to the Brazilian National Transplant System policy.

The grafting procedures have been described in details in a former study (11). Briefly, under local anesthesia, consisting of lidocaine 2\% with epinephrine 1:100,000 (DFL ${ }^{\circledR}$, Rio de Janeiro, RJ, Brazil), a full-thickness mucoperiosteal flap was elevated and the blocks were then adapted to the receptor bed and fixed with titanium screws by the horizontal augmentation onlay block grafting technique.

After the grafts' healing period (6 months), the planned implants were placed in the reconstructed sites according to manufacturer's specifications (Intra-lock ${ }^{\circledast}$, Boca Raton, $\mathrm{FL}, \mathrm{USA})$.

As part of the original investigation (11), within 7 days prior to the implant placement procedure, the patients had undergone a CBCT (I-Cat ${ }^{\circledR}$; Image Sciences International, Hatfied, PA, USA) scanning with $120 \mathrm{kVp}$ and $47 \mathrm{mAs}$ for $40 \mathrm{~s}$ with a $0.2 \mathrm{~mm}$ voxel size. The volume measurements of the block grafts were recorded for each patient.

Before the procedures reported in this study, the individuals were submitted to new CBCT scan using the same tomograph device and features, and the current volume measurements were compared with the previous baseline recordings.

At the time of either mucogingival surgery or the placement of additional implants, the patients received loco-regional anesthesia with lidocaine $2 \%$ and epinephrine 1:100,000 (DFL) and a full thickness flap was elevated exposing the previously grafted site. Next, a bone biopsy was removed exclusively from the grafted ridge using a trephine drill. The collected samples were $2.5 \mathrm{~mm}$ diameter and $4 \mathrm{~mm}$ deep. Fragments were preserved in 10\% buffered formalin and were sent to histological analysis. After the sample collection, the surgical procedure followed its original proposition.

\section{Tomographic Analysis}

Tomographic measurements were made utilizing a computer software (Dental Slice Converter ${ }^{\odot}$ BioParts, Bauru, SP, Brazil) and were performed by a single operator according to a previous validated method (12). Bone blocks were virtually isolated on the CBCT images using the software selection tool. The volume $(\mathrm{mm} 3)$ for each block was calculated by the software. The baseline and current volumetric assessments were compared.

\section{Histological Analysis}

The harvested bone graft samples were decalcified in $5 \%$ nitric acid, embedded in paraffin and stained with hematoxylin and eosin following the standard procedure of the Laboratory of Oral Pathology, School of Dentistry, UERJ - State University of Rio de Janeiro. The sections were evaluated by optical microscopy at 100x, 200x and 400x using a Leica DM500 light microscope (Leica Microsystems, Wetzlar, Germany). Evaluated parameters were the presence of healthy bony tissue, osteoblasts/osteocytes, vascular tissue, non-vital allograft remains and inflammatory cell infiltration.

\section{Clinical, Tomographic and Histological Findings}

The bone grafts were clinically sound and demonstrated a tight union to the recipient site at the time of their exposure. When penetrated with the trephine bur, all of the 4 grafts exhibited intra-osseous bleeding as would be expected from vital bony tissue, demonstrating clinical evidence of vascularization. All dental implants close to the trephined sites presented signs of healthy bone and mucosal tissue around them. The features for each patient are in Table 1.

Allograft resorption after implant loading was evidenced by comparing the tomographic images (Figs. $1 \mathrm{~A}$ and $1 \mathrm{~B}$ ). The volume changes varied from 2.1 to $7.7 \%$ in the cases. Although the grafts presented different degrees of volume reduction, none of the implants was exposed or showed bone fenestration.

Histological evaluation of the samples demonstrated well-incorporated grafts with different degrees of remodeling. The biopsies showed an abundant number 
of osteocytes within the sections as well as osteoblasts lining the edges of calcified structures. Inflammatory cell infiltration ranged from none to discrete and there were signs of vascularization in all the evaluated biopsies (Figs. $2 \mathrm{~A}, 2 \mathrm{~B}$ and $2 \mathrm{C}$ ).

Osteocytes lacunae with no nucleus were evident in patient number 2, where a cortico-cancellous tibial graft was used (Fig. 2D). This feature was clearly identified in the superficial layers of the graft, at the level of the cortical plate. At deeper sections and in the other 3 patient samples, few non-vital graft remains were found.

\section{Discussion}

Successful bone augmentation of extremely resorbed alveolar ridges remains a challenging goal to achieve. Although short-term studies have demonstrated promising results with the use of fresh-frozen bone block allografts (4), no long-term histological data are available regarding its performance and resorption characteristics following implant placement and loading.

During the incorporation phase, bone allografts show histologically new bone ingrowth, as evidenced by the presence of an osteogenic cell population, vascularization and a discrete inflammatory response with remains of non-incorporated grafted bone 4 to 9 months following reconstruction surgery $(11,13)$.

Biopsies of bone allografts after long term are reported only in orthopedic studies $(9,10)$ where there is often need to revise the surgical grafted sites. Analysis of allografts used in orthopedic surgeries after up to four years followup showed non-vital incorporated remains in samples from functional grafted areas. This data is still lacking in dentistry, as there is usually no need to re-enter surgically a grafted site after implant loading. Available histological reports from augmented ridges with allogeneic bone range from 3 to 10 months prior to implant placement $(14,15)$. Thus, long-term follow-up studies of block allografts in the dental literature are only based on clinical evaluation and implant survival assessments $(6,16-18)$. Several studies demonstrate that various amounts of residual allograft material still remain within the grafted areas at the time of implant placement $(8,19)$. Allograft incorporation and remodeling occurs via creeping substitution and it may be expected that little or no graft will remain after a period of time $(20,21)$. The present findings are in agreement with this hypothesis, as the biopsies of the grafted sites had a very similar appearance to the host's native bone. As stated in previous reports, remodeling of the allograft cortical

Table 1. Features for each patient and respective findings

\begin{tabular}{|c|c|c|c|c|c|c|c|c|c|c|}
\hline Case & Age & Gender & $\begin{array}{l}\text { Time from } \\
\text { grafting } \\
\text { (mo) }\end{array}$ & $\begin{array}{c}\text { Origin of } \\
\text { bone graft }\end{array}$ & Region & $\begin{array}{l}\text { Indication } \\
\text { for second } \\
\text { surgery }\end{array}$ & $\begin{array}{c}\text { Graft volume } \\
\text { at implant } \\
\text { placement } \\
\left(\mathrm{mm}^{3}\right)\end{array}$ & $\begin{array}{c}\text { Graft } \\
\text { volume at } \\
\text { reentry } \\
\left(\mathrm{mm}^{3}\right)\end{array}$ & $\begin{array}{c}\text { Graft } \\
\text { resorption } \\
(\%)\end{array}$ & Histologic features \\
\hline 1 & 47 & $\mathrm{~F}$ & 52 & $\begin{array}{c}\text { Cancellous } \\
\text { tibia }\end{array}$ & $\begin{array}{c}\text { Posterior } \\
\text { maxilla }\end{array}$ & $\begin{array}{l}\text { New implant } \\
\text { placement }\end{array}$ & 519.48 & 492.51 & 5.2 & $\begin{array}{c}\text { Vital bone along } \\
\text { with few allograft } \\
\text { remains } \\
\text { Vascular tissue } \\
\text { No inflammatory } \\
\text { infiltrate }\end{array}$ \\
\hline 2 & 37 & M & 44 & $\begin{array}{l}\text { Cortico- } \\
\text { cancellous } \\
\text { tibia }\end{array}$ & $\begin{array}{l}\text { Posterior } \\
\text { maxilla }\end{array}$ & $\begin{array}{c}\text { New implant } \\
\text { placement }\end{array}$ & 587.70 & 575.94 & 2.1 & $\begin{array}{c}\text { Osteocytes' lacunae } \\
\text { with no nucleus on } \\
\text { the outer layers } \\
\text { Vascular tissue } \\
\text { New bone } \\
\text { formation on } \\
\text { allograft surface } \\
\text { No inflammatory } \\
\text { infiltrate }\end{array}$ \\
\hline 3 & 61 & $\mathrm{~F}$ & 50 & Iliac crest & $\begin{array}{c}\text { Posterior } \\
\text { maxilla }\end{array}$ & $\begin{array}{l}\text { Mucogingival } \\
\text { surgery }\end{array}$ & 304.88 & 281.43 & 7.7 & $\begin{array}{c}\text { Vital bone } \\
\text { No sign of } \\
\text { allograft remains } \\
\text { Vascular tissue } \\
\text { No inflammatory } \\
\text { infiltrate }\end{array}$ \\
\hline 4 & 45 & $\mathrm{~F}$ & 47 & $\begin{array}{c}\text { Cancellous } \\
\text { tibia }\end{array}$ & $\begin{array}{c}\text { Anterior } \\
\text { maxilla }\end{array}$ & $\begin{array}{l}\text { Mucogingival } \\
\text { surgery }\end{array}$ & 613.72 & 590.39 & 3.8 & $\begin{array}{c}\text { Vital bone along } \\
\text { with few allograft } \\
\text { remains } \\
\text { Vascular tissue } \\
\text { No inflammatory } \\
\text { infiltrate }\end{array}$ \\
\hline
\end{tabular}


portion is expected to take longer than the cancellous portion $(22,23)$. This concurs with the conducted study, as the cortico-cancellous tibia graft sample had the largest amount of remaining original graft.
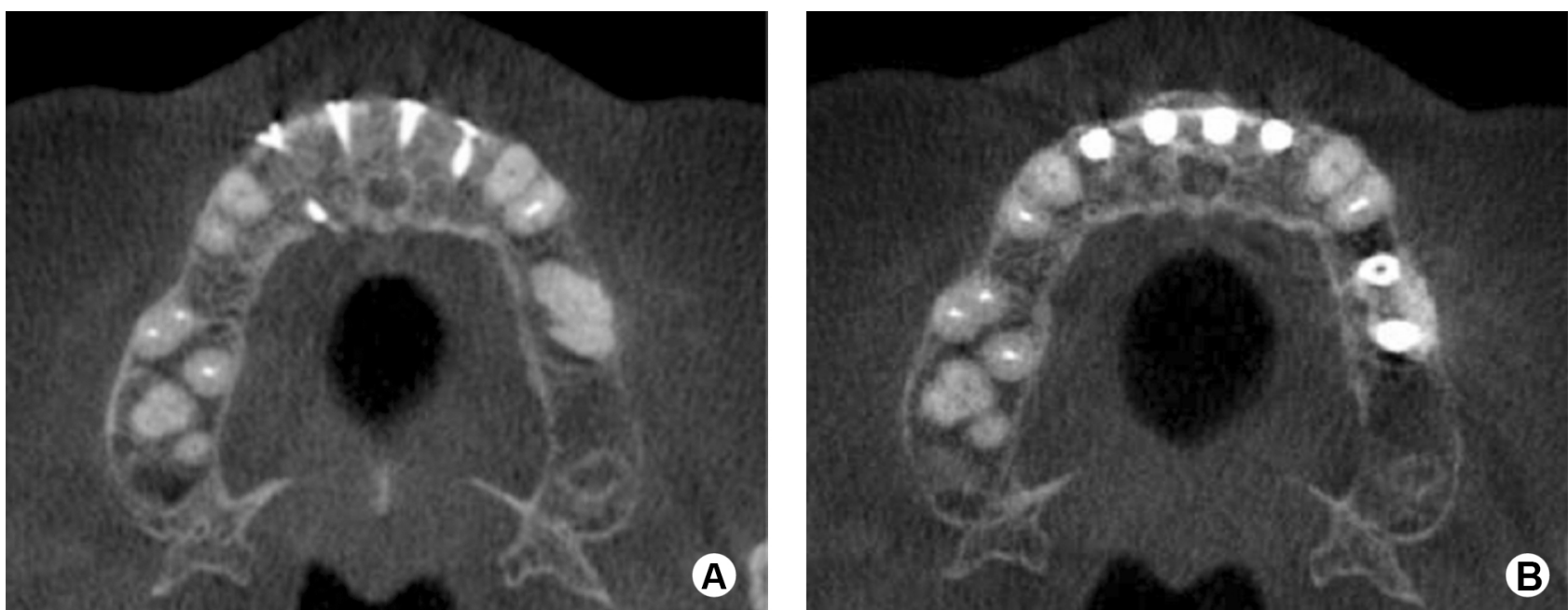

Figure 1. A: CBCT scan at the time of implant placement. B: CBCT scan 4-years after implant loading.
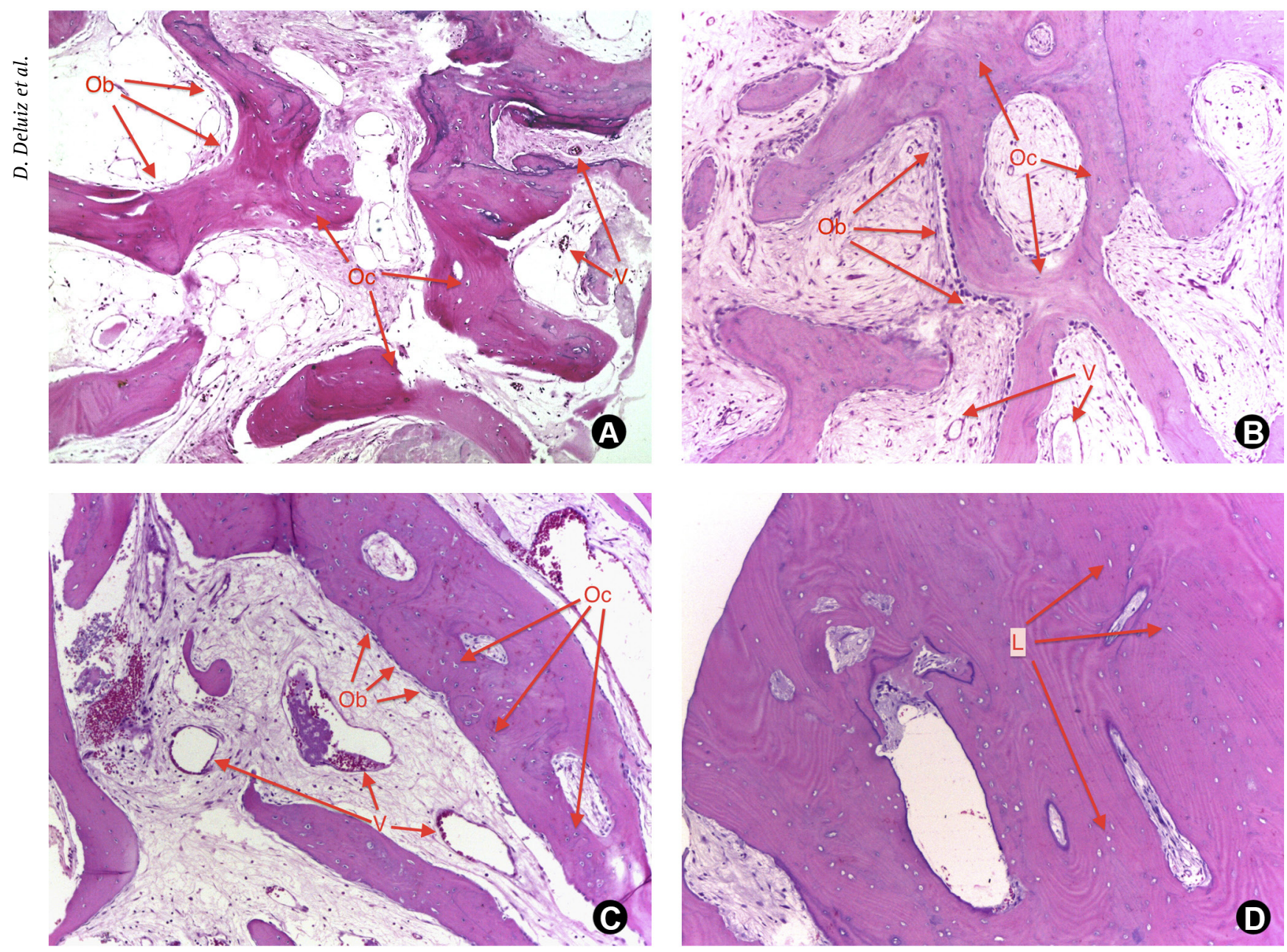

Figure 2. A, B and C: Healthy bone features with osteoblasts, osteocytes, vascular tissue and no inflammatory infiltrate (Ob: osteoblasts, Oc: osteocytes, V: vessels). D: Osteocytes empty lacunae on the superficial layers of the cortical graft (L: empty lacunae). 
Although many researchers describe the presence of "necrotic bone" in similar biopsies, no evidence of chronic or acute inflammation was present histologically or clinically $(24,25)$. Additionally, no surface or biochemical markers of necrotic cell death have been identified in the literature to affirm that the remaining non-vital graft has a necrotic nature (26). Furthermore, the presence of this non-vital segment did not impair the implant success or the health of the surrounding tissues, corroborating the orthopedic findings $(9,10)$.

During the regenerative process, it is expected that the bone allograft undergoes a volumetric resorption, which is influenced by the incorporation time prior to implant placement as well as the graft origin and the distribution between cortical and cancellous portions $(11,19)$. In the literature, there is no consensus of the ideal healing time prior to implant placement and there are wide variations in the reported resorption rates $(11,13)$. To date, few data regarding the FFBA behavior after long periods of occlusal loading are available.

Studies evaluating long-term incorporation of allografts in the alveolar ridge augmentation are difficult to design and this information is still lacking in the available literature. While the data presented in this report are from a small sample and does not allow definitive conclusions, its findings agree with the results reported in previous studies in the orthopedic field.

\section{Resumo}

0 objetivo deste artigo é relatar achados histológicos e tomográficos de aloenxertos ósseos em bloco com implantes dentários em oclusão funcional em um acompanhamento de longo prazo. Quatro pacientes com implantes funcionalmente carregados por 4 anos em rebordos alveolares enxertados, que necessitaram de cirurgia mucogengival ou instalação de implantes adicionais foram incluídos nesta série de casos. Imagens de tomografia cone-beam foram comparados volumetricamente entre o momento inicial (instalação do implante original) e imagens atuais. Biópsias dos enxertos foram coletadas e enviadas para análise histológica. A redução volumétrica dos enxertos variou entre $2,1-7,7 \%$. A avaliação histológica demonstrou enxertos bem incorporados com diferentes graus de remodelação. Embora os dados apresentados neste relato sejam de uma amostra pequena e não permitam conclusões definitivas, as biópsias dos sitios enxertados apresentaram características muito similares ao osso nativo. A remodelação da porção cortical dos aloenxertos parece levar mais tempo do que a porção esponjosa. A presença de remanescentes do enxerto não incorporado não demonstrou impacto no sucesso dos implantes ou na saúde dos tecidos circunjacentes. Este é o primeiro relato com dados histológicos e tomográficos em longo prazo de enxertos ósseos alógenos disponivel na odontologia.

\section{Acknowledgements}

Daniel Deluiz was granted a PhD scholarship from the Brazilian funding agency CAPES (Coordenação de Aperfeiçoamento de Pessoal de Nível Superior.

\section{References}

1. Misch CM. Maxillary autogenous bone grafting. Oral Maxillofac Surg
Clin North Am 2011;23:229-238.

2. Fernandes $M B C$, Guimarães JA, Casado $P$, Cavalcanti $A$ dos, Gonçalves $N N$, Ambrósio CE, et al.. The effect of bone allografts combined with bone marrow stromal cells on the healing of segmental bone defects in a sheep model. BMC Vet Res 2014;10:36.

3. Silva FMS, Cortez ALV, Moreira RWF, Mazzonetto R. Complications of intraoral donor site for bone grafting prior to implant placement. Implant Dent 2006;15:420-426.

4. Monje A, Pikos MA, Chan H, Suarez F, Gargallo-Albiol J, HernándezAlfaro $F$, et al.. On the feasibility of utilizing allogeneic bone blocks for atrophic maxillary augmentation. Biomed Res Int 2014;2014:1-12.

5. Messora M, Braga L, Oliveira G, Oliveira LF, Milagres R, Kawata L, et al.. Healing of fresh frozen bone allograft with or without platelet-rich plasma: A histologic and histometric study in rats. Clin Implant Dent Relat Res 2013;15:438-447.

6. Krasny $M$, Krasny $K$, Fiedor $P$, Zadurska $M$, Kamiński A. Long-term outcomes of the use of allogeneic, radiation-sterilised bone blocks in reconstruction of the atrophied alveolar ridge in the maxilla and mandible. Cell Tissue Bank 2015;16:631-638.

7. Pereira E, Messias A, Dias R, Judas F, Salvoni A, Guerra F. Horizontal resorption of fresh-frozen corticocancellous bone blocks in the reconstruction of the atrophic maxilla at 5 months. Clin Implant Dent Relat Res 2015;17:e444-e458.

8. Spin-Neto R, Stavropoulos A, Pereira LAVD, Marcantonio E, Wenzel A. Fate of autologous and fresh-frozen allogeneic block bone grafts used for ridge augmentation. A CBCT-based analysis. Clin Oral Implants Res 2013;24:167-173.

9. Hamer AJ, Suvarna SK, Stockley I. Histologic evidence of cortical allograft bone incorporation in revision hip surgery. J Arthroplasty 1997;12:785-789.

10. Gouin F, Passuti N, Verriele V, Delecrin J, Bainvel J V. Histological features of large bone allografts. J Bone Joint Surg Br 1996;78(1):3841.

11. Deluiz D, Oliveira LS, Pires FR, Tinoco EMB. Time-dependent changes in fresh-frozen bone block grafts: tomographic, histologic, and histomorphometric findings. Clin Implant Dent Relat Res 2015;17:296306.

12. Deluiz D, Deluiz LF, Veiga LDM, Muniz E, Tinoco B. Validation of a method using cone beam computed tomography for measuring bone block grafts for the alveolar ridge augmentation. Musculoskelet Regen 2016;2:e1312.

13. Contar CMM, Sarot JR, da Costa MB, Bordini J, de Lima AAS, Alanis LRA, et al.. Fresh-frozen bone allografts in maxillary ridge augmentation: histologic analysis. J Oral Implantol 2011;37:223-231.

14. Morelli T, Neiva R, Wang H-L. Human histology of allogeneic block grafts for alveolar ridge augmentation: case report. Int J Periodontics Restorative Dent 2009;29:649-656.

15. Lumetti S, Consolo U, Galli C, Multinu A, Piersanti L, Bellini P, et al.. Fresh-frozen bone blocks for horizontal ridge augmentation in the upper maxilla: 6-month outcomes of a randomized controlled trial. Clin Implant Dent Relat Res 2014;16:116-123.

16. Carinci $F$, Brunelli G, Zollino I, Franco $M$, Viscioni $A$, Rigo $L$, et al.. Mandibles grafted with fresh-frozen bone: an evaluation of implant outcome. Implant Dent 2009;18:86-95.

17. Carinci F, Guidi R, Franco M, Viscioni A, Rigo L, De Santis B, et al.. Implants inserted in fresh-frozen bone: a retrospective analysis of 88 implants loaded 4 months after insertion. Quintessence Int 2009 May;40:413-419.

18. Viscioni A, Franco M, Rigo L, Guidi R, Spinelli G, Carinci F. Retrospective study of standard-diameter implants inserted into allografts. J Oral Maxillofac Surg 2009;67:387-393.

19. Spin-Neto R, Stavropoulos A, Coletti FL, Pereira LA. VD, Marcantonio E, Wenzel A. Remodeling of cortical and corticocancellous fresh-frozen allogeneic block bone grafts - a radiographic and histomorphometric comparison to autologous bone grafts. Clin Oral Implants Res 2015;26:747-752.

20. Goldberg VM, Stevenson S. Natural history of autografts and allografts. Clin Orthop Relat Res 1987;(225):7-16.

21. Keith JD, Petrungaro P, Leonetti JA, Elwell CW, Zeren KJ, Caputo C, et 
al.. Clinical and histologic evaluation of a mineralized block allograft: results from the developmental period (2001-2004). Int J Periodontics Restorative Dent 2006;26:321-327.

22. Merkx M, Maltha JC, Freihofer HP, Kuijpers-Jagtman M. Incorporation of three types of bone block implants in the facial skeleton. Biomaterials 1999;20:639-645.

23. Matsumoto MA, Filho HN, Francischone $A E$, Consolaro A. Microscopic analysis of reconstructed maxillary alveolar ridges using autogenous bone grafts from the chin and iliac crest. Int J Oral Maxillofac Implants. 2002;17:507-516.

24. Kim S-G, Park J-S, Lim S-C. Placement of implant after bone graft using
J block allograft. Implant Dent 2010;19:21-28.

25. Spin-Neto R, Landazuri Del Barrio RA, Pereira LAVD, Marcantonio RAC, Marcantonio E, Marcantonio E. Clinical similarities and histological diversity comparing fresh frozen onlay bone block allografts and autografts in human maxillary reconstruction. Clin Implant Dent Relat Res 2013;15:490-497.

26. Krysko D V., Berghe T Vanden, Parthoens E, D'Herde K, Vandenabeele P. Chapter 16 Methods for Distinguishing Apoptotic from Necrotic Cells and Measuring Their Clearance. Methods Enzymol 2008;442:307-341.

Received June 1, 2016

Accepted September 30, 2016 